\title{
Edaphic arthropods in different successional stages of Atlantic forest and abandoned pasture areas
}

Cláudia dos Reis Ferreira', Rodrigo Camara de Souza', Maria Elizabeth Fernandes Correia², Alexander Silva de Resende², Lúcia Helena Cunha dos Anjos', Marcos Gervasio Pereira*1

' Federal Rural University of Rio de Janeiro, Seropédica, RJ, Brazil ${ }^{2}$ Embrapa Agrobiology, Seropédica, RJ, Brazil

*Corresponding author, e-mail: mgervasiopereira01@gmail.com

\begin{abstract}
The vegetation may modifies the structure and composition of the community of edaphic arthropods. This study aimed to compare the community of edaphic arthropods in four areas of abandoned pasture (AP1, AP2, AP3, AP4) and four secondary native forest fragments in a successional gradient (FF1, FF2, FF3, FF4), in Itaboraí, Rio de Janeiro, Brazil. The areas are positioned on the hillside and the sampling was conducted in transects outlined in a toposequence (upper, middle and lower sections), where pitfall traps were installed in the dry season. The organisms were identified in taxonomic groups (class, order and family). Comparing the averages for AP and FF, there was no defined pattern in terms of the response of structural attributes (total abundance, richness, uniformity and diversity). Among the areas of FF, higher values of all of the structural attributes occurred in the intermediate stages of forest succession (FF2, FF3), compared to the initial (FFl) and advanced stages (FF4). On average for the FF, the most favored groups were Archaeognatha, Coleoptera, Entomobryomorpha, Pseudoscorpionida, Psocoptera and Symphypleona. On average for the areas of AP, the most favored groups were Acari, Araneae, Formicidae, Diplopoda and Auchenorrhyncha. Among the areas of FF, Sternorryncha, Symphyla and Thysanura were favored in FFl, while Coleoptera, Psocoptera, Pseudoscorpionida, Entomobryomorpha and Archaeognatha were favored in the other successional stages (FF2, FF3, FF4
\end{abstract}

Keywords: bioindicator, forest fragmentation, forest regeneration.

\section{Introduction}

The edaphic fauna acts in the dynamics of the biogeochemical transformations of the soil organic material, directly (fragmentation of litter) and indirectly (stimulus and regulation of microorganism populations) (Correia \& Andrade, 2008). In fact, the animals that inhabit the soil, in part or at all stages of their life cycle, act in the processes of decomposition and mineralization of litter in different ways (Baretta et al., 2011). This depends fundamentally on the trophic guild to which the organisms belong, since according to this criterion there are groups of herbivores, saprophagous, microphages and predators. In addition, the activity of edaphic organisms can occur at the leaf litter-soil interface and / or in the more superficial layers of the soil (Araujo et al., 2010; Sabu et al., 2011).

The edaphic fauna is very sensitive to the characteristics of the ecosystem and, therefore, modifications caused in the environments are reflected in drastic alterations in the structure and composition of its community (Camara et al., 2012; Machado et al., 2015). This fact is strongly influenced by the characteristics of the plant community. Firstly, changes in the composition of plants are reflected in the modification of the organic residue available on the soil surface, which are food resources for the guilds of herbivorous organisms and decomposers, respectively. These, 
in turn, are food resources for predators.

Moreover, in the specific case of native forest ecosystems, the substitution of this ecosystem to other soil management practices has led to the fragmentation and simplification of the forest structure (Martins et al., 2011). Consequently, small forest fragments appear in the landscape, in different stages of succession, disconnected from each other, highly susceptible to edge effects and interspersed by pasture and commercial plantations. Thus, abiotic conditions, such as the incidence of solar radiation, temperature and soil moisture content, are modified (Siqueira et al., 2004; Fernandes et al., 2011).

As a result, changes in the structure and composition of plant communities (Gomes et al., 2009; Holland et al., 2010) and soil arthropods (Menezes et al., 2009; Machado et al., 2015), impact the biogeochemical dynamics of nutrients (Gomes et al., 2010; Pereira et al., 2013). In general, the community composition of these edaphic organisms is altered, as well as their abundance / density / biomass, richness and diversity, whose values are generally lower in pasture areas and monospecific forest plantations, in relation to native forest fragments (Decaëns et al., 2004; Moço et al., 2005; Copatti \& Daudt, 2009; Cunha \& Orlando, 2011; Martins et al., 2011).

In the remnants of native secondary forest, which develop after the abandonment of anthropic activities, edaphic arthropod communities present greater abundance / density, richness and diversity when compared to areas with more advanced successional stages (Menezes et al., 2009; Camara et al., 2012; Machado et al., 2015). These changes in the edaphic arthropod community may negatively affect the functioning of ecosystems (Hooper et al., 2005).

Therefore, the soil fauna has been used as a biological indicator of soil quality in studies comparing the characteristics of its community in disturbed environments, in different degrees or successional stages, with more mature ecosystems that are considered as a reference (Decaëns et al., 2004; Moço et al., 2005; Copatti \& Daudt, 2009; Menezes et al., 2009; Cunha \&
Orlando, 2011; Martins et al., 2011; Camara et al, 2012; Machado et al, 2015). Studies of this nature may indicate the areas in which human intervention is necessary to facilitate ecological recovery. However, it is still necessary to identify clear response of soil arthropods regarding the changes during forest regeneration to strengthen the use of these organisms as a bioindicator tool in evaluating environment impact (Sylvain \& Wall, 2011).

The aim of this study was to evaluate the influence of two different types of soil cover, pasture and native forest, and four different successional stages of Atlantic Forest, on the edaphic arthropod community.

\section{Material and Methods}

The study area is located between latitudes $22^{\circ} 40^{\prime} 30$ "S and $22^{\circ} 38$ '42" S, and longitudes $42^{\circ} 48^{\prime} 54$ " $\mathrm{W}$ and $42^{\circ} 47^{\prime} 42^{\prime \prime} \mathrm{W}$, in the municipality of Itaboraí, Rio de Janeiro, Brazil. The climate of the region is tropical, with rainy summer and dry winter (Aw) (Köppen, 1948). The average annual temperature is $21.4^{\circ} \mathrm{C}$, achieving highest and lowest values in February $\left(24.5^{\circ} \mathrm{C}\right)$ and July $\left(18.2^{\circ} \mathrm{C}\right)$, respectively (Gonçalves, 2014). The total annual rainfall is $1,461 \mathrm{~mm}$, most of which is concentrated in summer (from November to April), with higher precipitation in December (213 $\mathrm{mm}$ ) and lower in June (47 mm) (Gonçalves, 2014). The predominant soil class is the yellow Latosol (Gomes et al., 2014).

The original vegetation belongs to the domain of the Lowland and Submontane Dense Ombrophylous Forest (Veloso et al., 1991), most of which was eliminated for pasture and agricultural crops, as well as for the extraction of wood, sand and clay. The area matrix corresponds to abandoned pasture with few secondary forest fragments smaller than 5 ha at the top of the slopes. Part of the studied area is influenced by the Rio de Janeiro Petrochemical Complex (COMPERJ) and was expropriated in 2007 for the planting of seedlings of native forest species and the implementation of conservation units that integrate the Central Atlantic Forest Mosaic of the Rio de Janeiro State (Fidalgo et al., 2014). In the eastern portion of the expropriated area, a polygon was delimited to perform water, fauna, 
flora and soil monitoring studies (Fidalgo et al., 2014; Gomes et al., 2014; Uhlmann et al., 2014).

For the present study, four Atlantic Forest forest fragments in different successional stages (FF1, FF2, FF3 and FF4) and four abandoned pasture areas (AP1, AP2, AP3 and AP4) were selected (Figure 1). According to Uhlmann et al. (2014), the FF4 tree community was in a more advanced stage of natural regeneration (higher values of richness, S: 37 , and diversity, $\left.H^{\prime}: 3,17\right)$, followed by FF3 (S: 28; H': 2.39) and FF2 (S: 16; H': 1.63), whose successional stages were characterized as intermediates, and $\mathrm{FFl}$, which was at a less advanced stage (S: 15, H': 1.11).

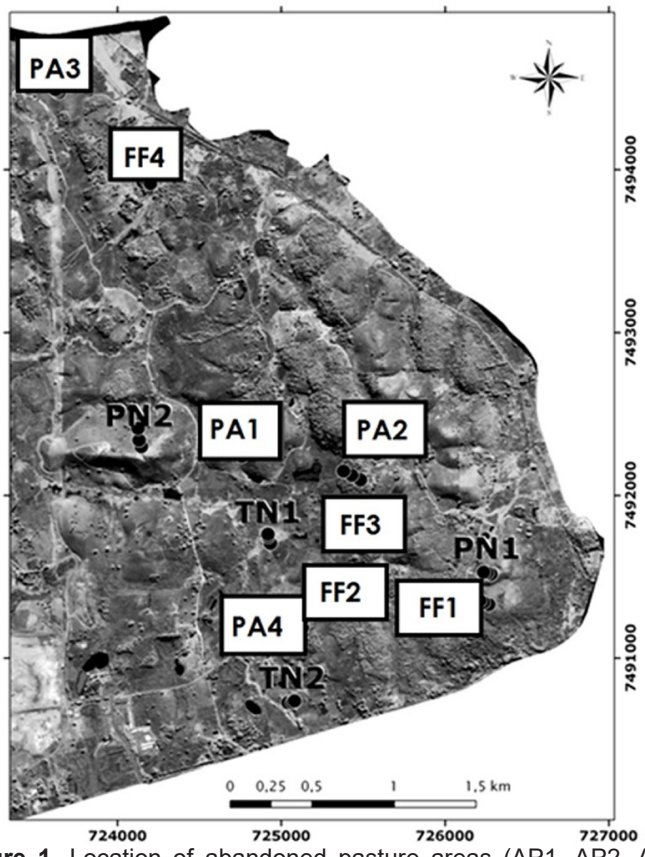

Figure 1. Location of abandoned pasture areas (AP1, AP2, AP3, AP4) and forest fragments in four different successional stages (FF1, FF2, FF3, FF4) in Itaboraí, RJ, Brazil. Source: Fidalgo et al. (2014). Note: areas marked as PN1, PN2, TN1 and TN2 were not object of the present study.

Uhlmann et al. (2014) observed that 59\% of the sampled individuals (circumference at breast height $\geq 15 \mathrm{~cm}$ ) belonged to eight species: Attalea humilis Mart. (16\%), Leguminous 1 (12\%), Gochnatia polymorpha (Less.) Cabrera (6 \%), Albizia pedicellaris (DC.) L. Rico (6\%), Casearia sylvestris Sw. (6\%), Matayba guianensis Aubl. (5\%), Guapira opposita (Vell.) Reitz (4\%) e Machaerium brasiliense Vogel (4 \%) in FF4. In FF3, 70\% of the sampled plants corresponded to representatives of four species: Attalea humilis (31\%), Cupania sp. 2 (21\%), Astrocaryum aculeatissimum (Schott) Burret (10\%) and Nectandra sp. 1 (8\%). In FF2, 77\% of the tree community was represented by three species: Gochnatia polymorpha (59\%), Attalea humilis (10\%) and Machaerium brasiliense (8\%). In FF1, $83 \%$ of the whole community belonged to only two species: Gochnatia polymorpha, whose predominance was even greater $(77 \%)$ than in FF2, followed by Luehea grandiflora Mart. \& Zucc. (6\%).

Regarding the abandoned pasture areas, Brachiaria decumbens Stapf predominates in AP1 and AP2, while in AP3 and AP4 the predominance of Brachiaria humidicola (Rendle) Schweick occurs. Gomes et al. (2014) observed differences between the two types of soil cover in relation to the chemical attributes of the soil surface horizon (A or Ap). According to these authors, in the average of the forest fragments, the values of assimilable phosphorus (P: $2.43 \mathrm{dag} \mathrm{kg}^{-1}$ ), exchangeable aluminum (Al: 2.17 cmolc $\left.\mathrm{dm}^{-3}\right)$, potential acidity $(\mathrm{H}+\mathrm{Al}$ : 9,27 Cmolc $\mathrm{dm}^{-3}$ ), aluminum saturation ( $\mathrm{m} \%: 77 \%$ ) and cation

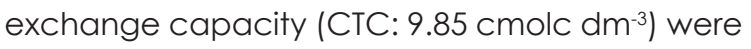
higher than the average of abandoned pasture areas (P: $1.58 \mathrm{dag} \mathrm{Kg}^{-1}, \mathrm{Al}: 1.45 \mathrm{cmolc}^{-\mathrm{dm}^{-3}}, \mathrm{H}$ + Al: $6.79 \mathrm{cmolc}^{\left.-\mathrm{dm}^{-3}\right)}$ and cation exchange

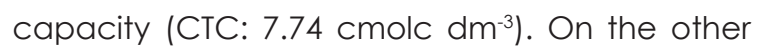
hand, higher values of $\mathrm{pH}\left(\mathrm{pH}\right.$ in $\mathrm{CaCl}_{2}$ : 3.8),

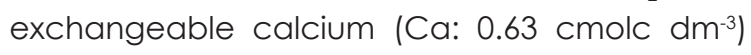
and base saturation (V\%: $13 \%$ ) occurred in the abandoned pasture when compared to the forest fragments ( $\mathrm{pH}$ in $\mathrm{CaCl}_{2}: 3.5, \mathrm{Ca}: 0.31 \mathrm{cmolc}$ $\mathrm{dm}^{-3}, \mathrm{v \%}$ : 6\%) (Gomes et al., 2014).

Forest fragments and abandoned pasture areas are located in sloping areas. For this reason, each of the sites was subdivided into three sections according to the vertical gradient: upper, middle and lower thirds. In each of these sections a transect was delimited, where six traps were installed for soil arthropod sampling in the dry season of 2010. The traps, which were considered sample units, were spaced $5 \mathrm{~m}$, according to recommendations of Aquino (2001). In this way, 18 traps per area and a total of 144 traps were used in the study. The traps consisted of plastic containers $19 \mathrm{~cm}$ in diameter, $11 \mathrm{~cm}$ high) that were buried with the edge close to the soil surface and partially filled with preservative liquid (4\% formalin). After staying for seven days in the field, the traps were taken to the Embrapa Agrobiology Soil Fauna Laboratory. 
Then, with the aid of a pisset with distilled water, the contents of the traps were filtered, transferred to Petri dishes and stored in plastic vials $(10 \mathrm{~mL})$ with $70 \%$ alcohol, until the time of evaluation. The organisms were identified in taxonomic groups (class, order and family) (CSIRO, 1991). Formicidae was considered a different taxonomic group from Hymenoptera due to the ease of identification. The Collembola class was subdivided into three taxonomic groups: Entomobryomorpha, Poduromorpha and Symphypleona. Adult individuals were separated from larval forms due to the differences between these vital phases in their ecological role in the edaphic environment, even when they belong to the same taxonomic group.

All data obtained from the edaphic arthropod community were analyzed in order to compare: (1) the average for the forest and the abandoned pasture areas; (2) the forest fragments in different successional stages. The values of total abundance and abundance of taxonomic groups (Ab, number of individuals trap $^{-1}-d_{a y} y^{-1}$, expressed as ind trap ${ }^{-1} d a y^{-1}$ ) were estimated by dividing the mean number of individuals per trap and the number of days that the traps remained in the field (Camara et al., 2012). The relative participation (\%) of the taxonomic groups was calculated according to the ratio between the abundance of the groups and the total abundance of the community. Taxonomic groups with a relative participation of less than $2 \%$ were collected under the denomination "Other". The values of richness ( $R$, total number of groups), uniformity (U, Pielou index) and diversity $(H$ ', Shannon index) were also estimated.

The values of total abundance and abundance of groups were submitted to analysis of variance and the means were compared by the Kruskal-Wallis non-parametric test at $5 \%$ of significance with the aid of the BioEstat software, version 5.3 (Mamirauá Institute, Belém, Brazil). Principal component analysis (PCA) was also performed with the objective of identifying the taxonomic groups that could be used to differentiate the areas. For this, it was considered the average abundance of taxonomic groups that presented correlation coefficients above
$0.70 \%$ with one of the main axes: axis 1 or axis 2. The multivariate analysis was processed using PAST software version 2.17c (Hammer et al. Al., 2001).

\section{Results and Discussion}

Comparing the eight studied areas, a significant difference was observed only between FF1 and FF2, since the value of total abundance was lower in the first fragment, when compared to the second one (Table 1). The mean value of total abundance in the forest fragments was not significantly different from that observed for the average of the pasture area (Table 1). This pattern was previously observed in another area in the southeast region of the country, since there were no differences among forest fragments at different stages of succession and pasture areas when considering the total density of the edaphic arthropod community (Menezes et al., 2009). However, a pasture area presented a lower total density of these organisms when compared to preserved and non-preserved fragments of the Atlantic Forest, in the northern region of Rio de Janeiro State (Moço et al., 2005).

Comparing the forest fragments, the highest values of richness of the edaphic arthropod community were observed in the forest fragments in intermediate successional stages, FF2 and FF3, followed by the forest fragments in the advanced and initial successional stages, FF4 and FFI, respectively (Table 1). Forest ecosystems with higher values of richness and diversity of the tree community also have a community of edaphic arthropods with higher values of richness (Copatti \& Daudt, 2009; Camara et al., 2012). This fact is due to the response of soil arthropods to a more heterogeneous litter layer with greater nutritional diversity in areas with a more diverse community of plants (Correia \& Andrade, 2008).

Therefore, due to the higher values of richness and diversity of the plant community in FF4 in relation to the others (UhImann et al., 2014), it was expected that the greatest value of richness for the soil arthropod community occurred in that fragment. Machado et al. (2015) obtained this result of increased soil arthropod richness as a function of an increasing gradient of Atlantic Forest succession. 
Tablel 1. Abundance $(A b)^{*}$, richness $(S)$, uniformity $(U)$ and diversity $\left(H^{\prime}\right)$ of the the edaphic arthropod community in forest fragments at different successional stages (FF1, FF2, FF3, FF4) and abandoned pasture areas (AP1, AP2, AP3 e AP4) in Itaboraí, RJ, Brazil**

\begin{tabular}{|c|c|c|c|c|c|}
\hline \multirow{2}{*}{$\begin{array}{l}\text { Structural attributes of the edaphic } \\
\text { arthropod community }\end{array}$} & \multicolumn{5}{|c|}{ Forest fragments } \\
\hline & FFl & FF2 & FF3 & FF4 & Mean \\
\hline $\mathrm{Ab}$ & $13.29 a(1.23)$ & $24.98^{b}(3.82)$ & $16.87^{\mathrm{ab}}(2.83)$ & $17.19 \mathrm{ab}(1.71)$ & $18.09^{A}(2.74)$ \\
\hline$S$ & 23 & 27 & 27 & 24 & 32 \\
\hline U & 0.53 & 0.47 & 0.57 & 0.49 & 0.52 \\
\hline \multirow[t]{3}{*}{$\mathrm{H}^{\prime}$} & 2.41 & 2.25 & 2.72 & 2.25 & 2.41 \\
\hline & \multicolumn{5}{|c|}{ Abandoned pasture areas } \\
\hline & $\mathrm{APl}$ & AP2 & AP3 & AP4 & Mean \\
\hline $\mathrm{Ab}$ & $18.06(3.52)$ & $16.11(1.41)$ & $18.44(2.05)$ & $16.74(1.42)$ & $17.34^{\mathrm{A}}(1.69)$ \\
\hline$S$ & 25 & 19 & 20 & 20 & 26 \\
\hline U & 0.52 & 0.50 & 0.59 & 0.85 & 0.62 \\
\hline $\mathrm{H}^{\prime}$ & 2.44 & 2.11 & 2.53 & 3.68 & 2.69 \\
\hline
\end{tabular}

Other factors besides the chemical nature of the leaf litter may be more important in for the structure conditioning of the edaphic arthropod community.

Sayad et al. (2012) observed that greater mass of litter standing stock on the soil surface in forest ecosystems is a decisive factor for the greater richness of these organisms, despite the leaf litter quality. This is due to the higher moisture content of the soil and refuges for edaphic arthropods, provided by the presence of a thicker leaf litter layer (Sayer, 2006). However, this can not be inferred for the studied forest fragments due to the lack of data concerning the litter thickness.

The richness value for the FF mean was higher than the the same value for AP (Table 1). This result are in accordance to the general pattern of lower values of soil arthropod community richness in pasture areas, compared to Atlantic Forest fragments (Moço et al., 2005; Cunha \& Orlando, 2011; Martins et al., 2011) and Amazon Forest (Decaëns et al., 2004; Mathieu et al., 2005). According to these authors, the greater structural complexity of the community of plants in forest fragments determines the greater variety of niches available, which contributes to the capacity of these ecosystems to support an edaphic arthropods community with greater richness, when compared to pasture areas. In addition, due to the smaller vegetation structure in pastures, in these areas the microclimatic conditions (temperature and soil moisture content) present more drastic variations and may be unfavorable and even exclude certain groups of edaphic arthropods, when compared to forest areas (Decaëns et al., 2004; Martins et al., 2011).

In environments with greater richness, it is believed that there is not only a greater number of species or groups interacting with each other and playing different ecological roles, but also a greater number of those playing a similar ecosystem role (functional redundancy) (Hooper et al. al., 2005). Only Archaeognatha and Psocoptera, both groups of saprophagous, the predators Chilopoda, Neuroptera and Pseudoscorpionida, besides Gastropoda, a group that involves saprophagous and herbivorous species, were sampled in the forest fragments. This may indicate that in these areas there are more stable and provide favorable conditions for edaphic arthropods.

In other studies, the presence of these taxonomic groups was not observed in pasture areas (Moço et al., 2015), being observed only in less disturbed environments of the Atlantic Forest, as in native forest and not in abandoned eucalyptus plantations (Camara et al., 2012), not in the edge of native vegetation (Pereira et al., 2013) and in forest fragments in intermediate and advanced successional stages, and not in that in early stages (Machado et al., 2015). The greater richness indicates that the ecosystem presents more complex ecological functioning and greater stability, which probably is the case of the studied forest fragments, compared to 
the areas of abandoned pasture (Hooper et al., 2005).

In general, Acari, Araneae, Coleoptera, Diptera, Formicidae, Orthoptera, Entomobryomorpha, Poduromorpha and Symphypleona were the groups that stood out, considering the observed values of abundance and relative participation (Figure 2). The others were grouped in "Others" (Table 2). However, when comparing the two types of soil management, there was a significant variation in the average abundance of some groups. In the FF mean, the abundance of Entomobryomorpha was higher, while the abundance of Acari and Formicidae was lower, compared to the mean for the AP (Figure 2).

The distribution of most of the individuals occurred in four groups, in the average of AP: Formicidae, Acari, Entomobryomorpha and Poduromorpha (Figure 2). On the other hand, more than half of the total individuals (52\%) concentrated on only one taxonomic group, Entomobryomorpha, on the FF average (Figure $2)$. Both values of uniformity and diversity were lower on the FF mean when compared to the mean for the APs (Table 1). This influenced the low uniformity, which directly affected the lowest diversity value, for the FF mean (Table 1 ).

Comparing the forest fragments for uniformity and diversity indices, the highest values

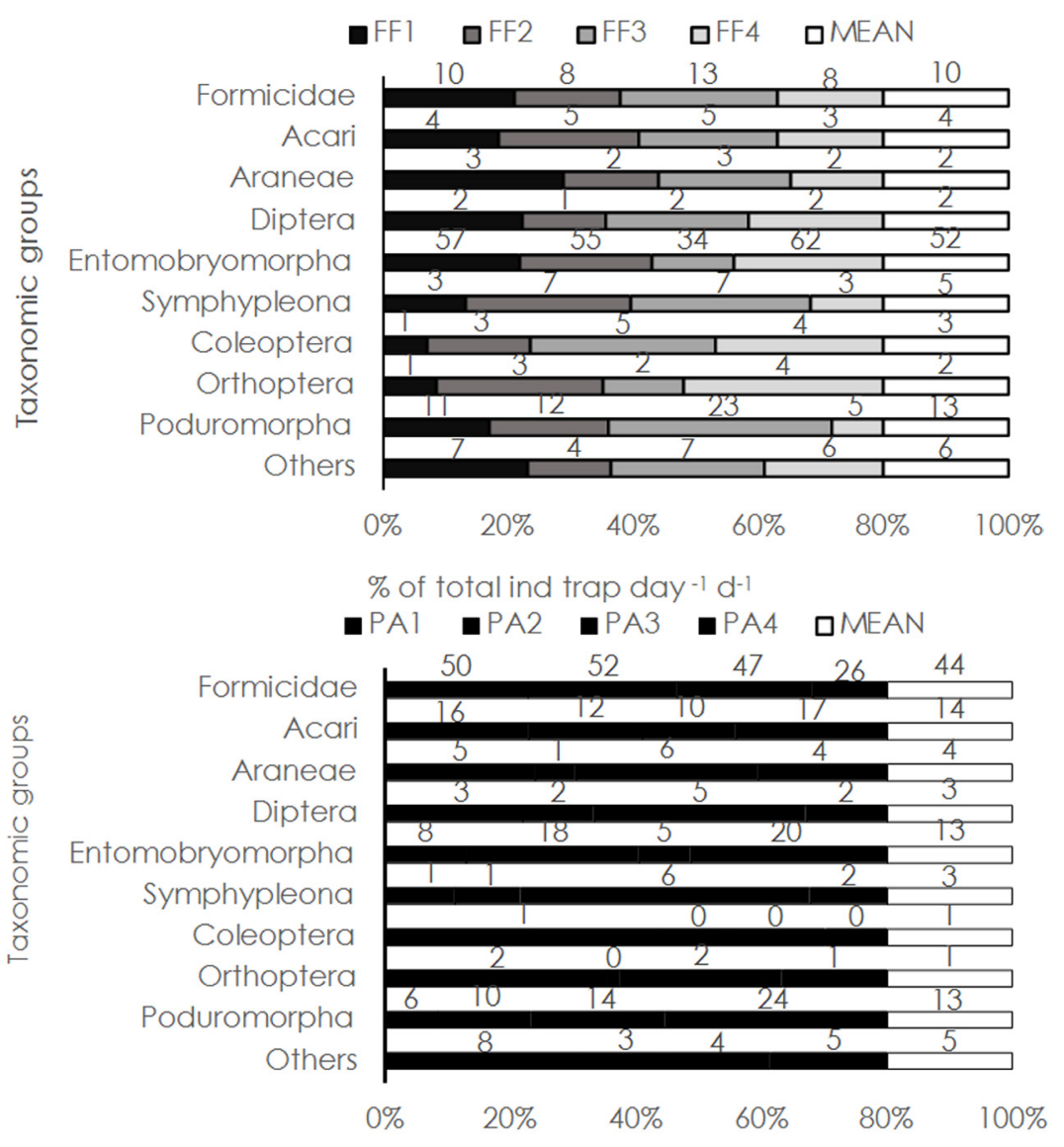

$\%$ of total de ind trap day ${ }^{-1} \mathrm{~d}^{-1}$

Figure 2. Participation of the taxonomic groups of edaphic arthropods in relation to the total community abundance (\% of the total ind ${ }^{-1} \operatorname{trap}^{-1} \mathrm{day}^{-1}$ ), for the mean of the forest fragments in different successional stages (FF), Itaboraí, RJ, Brazil.

were observed in FF3, while the intermediate values were verified in FF1 and the lowest in FF2 and FF4 (Table 1). On the other hand, Machado et al. (2015) verified a gradual increase in the values of uniformity in the dry season because of the development of the Atlantic Forest succession in Pinheiral, RJ, Brazil.

The pattern found in the present study for the uniformity and richness data during the dry season was also observed in Pinheiral, RJ, Brazil (Menezes et al., 2009). The authors of the mentioned study observed that a single group, 
Formicidae, presented significant relative Participation in three fragments of Atlantic Forest in different successional stages, whereas in pasture area the distribution of edaphic arthropods was more balanced, with the important participation of Coleoptera, Araneae, Isoptera and Coleoptera larvae, as well as Formicidae.

However, the results of the present study are partially in accordance to the results of

Table 2. Distribution of the taxonomic groups of edaphic arthropods classified as "Other", in the forest fragments (FF) and in the areas of abandoned pasture (AP), Itaboraí, RJ, Brazil

\begin{tabular}{|c|c|}
\hline Ecossistem & Taxonomic group \\
\hline FF & $\begin{array}{l}\text { Archaeognatha, Auchenorryncha, Blattodea, Chilopoda, Diplopoda, Gastropoda, } \\
\text { Heteroptera, Hymenoptera, Isopoda, Isoptera, Coleoptera larvae, Diptera larvae, } \\
\text { Lepidoptera larvae, Neuroptera larvae, Neuroptera, Oligochaeta, Opilionida, } \\
\text { Pseudoscorpionida, Psocoptera, Sternorryncha, Symphyla, Thysanoptera, Thysanura }\end{array}$ \\
\hline AP & $\begin{array}{l}\text { Auchenorryncha, Blattodea, Coleoptera, Diplopoda, Heteroptera, Hymenoptera, Isopoda, } \\
\text { Isoptera, Coleoptera larvae, Diptera larvae, Lepidoptera larvae, Neuroptera larvae, } \\
\text { Oligochaeta, Opilionida, Orthoptera, Sternorryncha, Symphyla, Thysanoptera, Thysanura }\end{array}$ \\
\hline
\end{tabular}

Moço et al. (2005), that verified higher values of uniformity and diversity in an area of preserved forest, intermediate in a pasture of Brachiaria decumbens with natural regeneration of some native species of Atlantic Forest, and smaller in a fragment of no-preserved forest in the winter (dry season), at the 'Desengano' State Park.

The divergence among these results, although the collection occurred in the same climatic season (dry season), probably occurred due to the use of different methods for the extraction of soil arthropods, since the present study used pitfall traps, while Moço et al. (2005) and Menezes et al. (2009) used Berlese funnels and manual extraction of organisms in monoliths (25 × $25 \times 10 \mathrm{~cm}$ depth), respectively.

The values of average abundance of Coleoptera, Entomobryomorpha and Symphypleona were significantly higher in the FF mean $(0.45 \pm 0.12,9.62 \pm 2.00,0.93 \pm 0.26$ ind trap $^{-1}$ day $^{-1}$, respectively), when compared to the mean for AP $10.09 \pm 0.05 ; 2.11 \pm 0.41 ; 0.46 \pm$ 0.16 ind trap $^{-1}$ day $^{-1}$, respectively). The opposite pattern occurred for the values of average abundance of Formicidae, Acari, Araneae and Diptera, which were higher in the mean of the $\operatorname{AP}(8.00 \pm 1.36,2.29 \pm 0.35,0.67 \pm 0.14,0.45 \pm 0.09$, respectively), in relation to the FF mean ( $1.49 \pm$

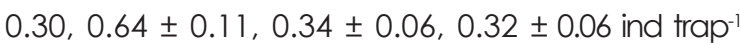
$\mathrm{day}^{-1}$, respectively). There were no differences between these ecosystems regarding the abundance of Orthoptera (FF: $0.50 \pm 0.42$ ind trap-1 day-1, AP: $0.22 \pm 0.07$ ind trap ${ }^{-1}$ day $^{-1}$ ), Poduromorpha (FF: $2.87 \pm 1.47$, AP: $2.28 \pm 0.58$ ind $\operatorname{trap}^{-1}$ day $^{-1}$ ) and 'Others' (FF: $1.59 \pm 0.00$, AP: 1.08 $\pm 0,00)$.

These results influenced the relative participation of these groups in the edaphic arthropod community, since it was higher in the FF average for Coleoptera, Entomobryomorpha and Symphypleona, whereas it was lower for Formicidae, Acari and Araneae, in the mean of the AP (Figure 2). As in the present study, Nakamura et al. (2007) also found that the values of abundance of Coleoptera and Araneae evaluated using pitfall traps were higher and lower, respectively, in the average for 12 areas with tropical forest in different successional stages, when compared to the average for 12 pasture areas in Australia.

In the comparison among FF in different stages of regeneration, there were no significant differences regarding the abundance of most of the taxonomic groups (Table 3). However, the abundance values of Coleoptera and Orthoptera increased, while the abundance of Poduromorpha decreased with the development of the successional stage. The absolute value of Orthoptera abundance in FF2 was higher than that verified for the other forest fragments. However, there was no significant difference among this fragment (FF2) and those with the lowest absolute values (FFI and FF3) of this taxonomic group due to the high standard error observed in FF2.

In the case of Entomobryomorpha, the abundance was higher in FF2 and FF4 than in FF3 and, for this reason, there was no clear pattern 
of variation in the abundance of this group throughout the successional process (Table 3). Concerning the relative participation of taxonomic groups, the dominance of Coleoptera, Orthoptera and Entomobryomorpha was higher as the natural regeneration gradient increased (Figure 2). The relative Participation of Acari,
Formicidae, Poduromorpha and Symphypleona was higher in at least one of the intermediate successional stages (FF2 and FF3). There was no clear pattern of alteration of the relative participation along the successional gradient for the groups Araneae, Diptera and Others.

Table 3. Mean values for abundance* of taxonomic groups of edaphic arthropods in forest fragments in different successional stages (FF1, FF2, FF3, FF4) in Itaboraí, RJ, Brazil**.

\begin{tabular}{lcccc}
\hline \multirow{2}{*}{ Taxonomic group } & FF1 & FF2 & FF3 & FF4 \\
\cline { 2 - 5 } & \multicolumn{4}{c}{ ind trap ${ }^{-1}$ day $^{-1}$} \\
\hline Acari & $0.48(0.09)$ & $0.87(0.10)$ & $0.60(0.10)$ & $0.62(0.13)$ \\
Araneae & $0.42(0.07)$ & $0.34(0.05)$ & $0.34(0.06)$ & $0.25(0.05)$ \\
Coleoptera & $0.13^{\mathrm{a}}(0.04)$ & $0.46^{\mathrm{ab}}(0.10)$ & $0.53^{\mathrm{b}}(0.11)$ & $0.68^{\mathrm{b}}(0.16)$ \\
Diptera & $0.29(0.06)$ & $0.26(0.04)$ & $0.31(0.06)$ & $0.40(0.08)$ \\
Formicidae & $1.35(0.31)$ & $1.67(0.27)$ & $1.71(0.35)$ & $1.23(0.24)$ \\
Orthoptera & $0.14^{\mathrm{a}}(0.09)$ & $1.02^{\mathrm{a}}(0.84)$ & $0.21^{\mathrm{a}}(0.05)$ & $0.63^{\mathrm{b}}(0.08)$ \\
Entomobryomorpha & $7.64^{\mathrm{ab}}(0.84)$ & $14.52^{\mathrm{b}}(13.29)$ & $5.38^{\mathrm{a}}(0.90)$ & $10.93^{\mathrm{b}}(1.27)$ \\
Poduromorpha & $1.40^{\mathrm{ab}}(0.20)$ & $3.40^{\mathrm{a}}(0.73)$ & $5.71^{\mathrm{a}}(2.75)$ & $0.94^{\mathrm{b}}(0.18)$ \\
Symphypleona & $0.44(0.10)$ & $1.66(0.38)$ & $1.09(0.23)$ & $0.52(0.13)$ \\
Others & $0.99(0.20)$ & $0.78(0.08)$ & $1.00(0.10)$ & $0.98(0.18)$ \\
\hline${ }^{*}$ Total abundance values for 18 repetitions. ${ }^{* *}$ Means followed by different letters indicate significant differences among the studied areas (forest fragments
\end{tabular}

*Total abundance values for 18 repetitions. ${ }^{* *}$ Means followed by different letters indicate significant differences among the studied areas (forest fragments and abandoned pastures) for the taxonomic group abundance, according to the Kruskal-Wallis non-parametric test $(p<0.05)$.

The principal component analysis fragments (Decaëns et al., 2004; Martins et al., (PCA) showed the separation between the main studied areas according to the principal component 1 (axis 1) and principal component 2 (axis 2). All APs were grouped in the left portion of axis 1 (negative values), while all FF were in the right portion of axis 1 (positive values) (Figure 3). Therefore, these two types of ecosystem, AP and $\mathrm{FF}$, presented contrasting ecological conditions for edaphic arthropods. In addition, axis 2 indicated that there was a segregation among $\mathrm{FF}$, since the fragment in the initial successional stage (FFl) was located in the upper portion (positive values), while the other $\mathrm{FF}$, which present intermediate (FF2 and FF3) and advanced (FF4) successional stages were grouped in the lower portion (negative values). The variability of the data explained was $59.32 \%$ in axis 1 and $20.09 \%$ in axis 2 , which corresponded to $79.42 \%$ of the variance.

Comparing to the FF, the AP set presented a correlation with the lowest part of the taxonomic groups of edaphic arthropods, especially Acari, Formicidae, Diplopoda and Auchenorrhyncha, in comparison with the AP set (Figure 3). Thus, the PCA reinforced the hypothesis that pasture areas are configured in environments less favorable to soil arthropods when compared to native forest 2011). FF2, FF3 and FF4 showed correlation with Coleoptera, Psocoptera, Pseudoscorpionida, Entomobryomorpha and Archaeognatha. Sternorryncha, Symphyla and Thysanura were correlated to FFl.

The present study demonstrated the occurrence of structural and compositional differences of the edaphic arthropod community between two types of soil cover, abandoned pasture and forest fragments areas, and between the four successive stages of the Atlantic Forest in the dry season, in Itaboraí, Rio de Janeiro, Brazil. Therefore, the role of the edaphic arthropod community as an important bioindicator of environmental impacts was affirmed.

\section{Conclusions}

A greater number of taxonomic groups of edaphic arthropods were observed in the Atlantic Forest fragments, among which Archaeognatha, Coleoptera, Entomobryomorpha, Pseudoscorpionida, Psocoptera and Symphypleona were the most favored.

There were no differences between forest fragments and pasture areas regarding the total abundance of the edaphic arthropod community. 


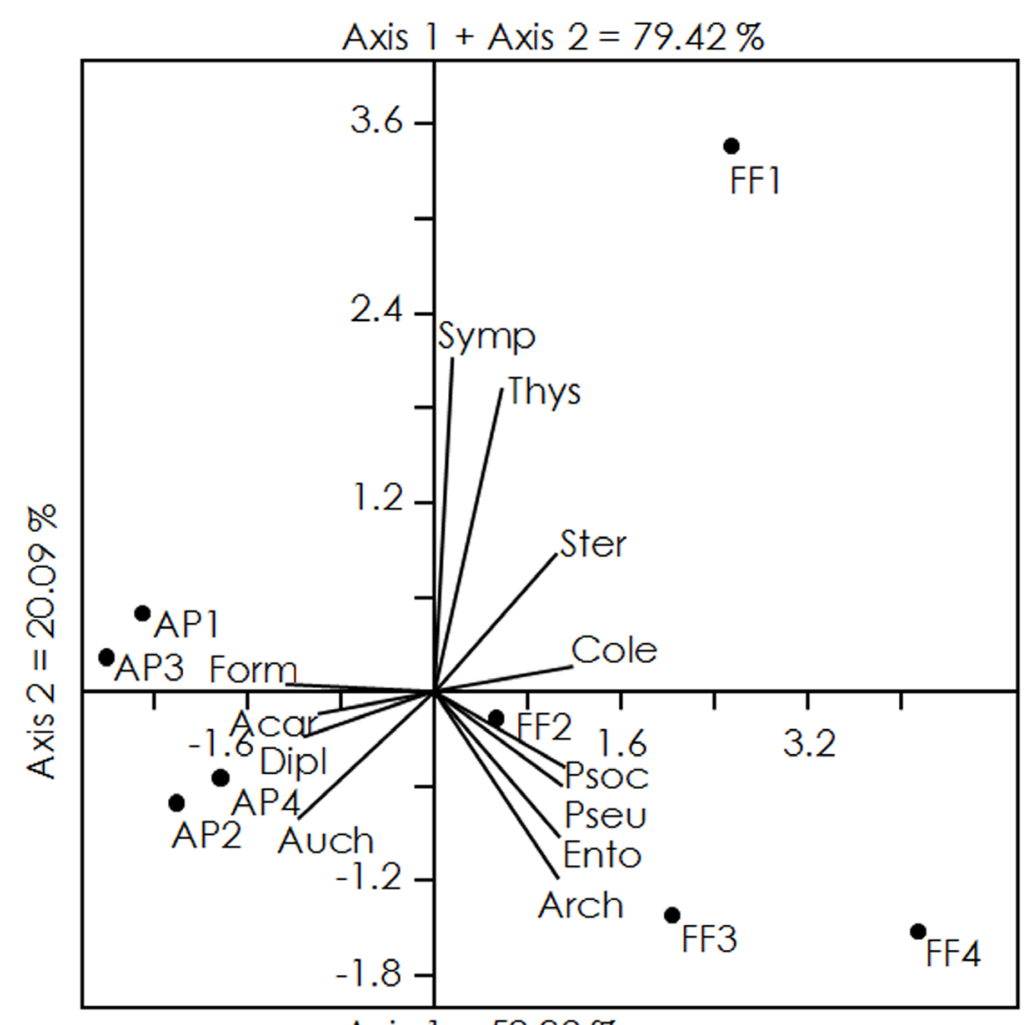

Axis $1=59.32 \%$

Figure 3. Principal component analysis for the abundance of edaphic arthtopods in the forest fragments at diferente successional stages (FF1, FF2, FF3, FF4) and areas of abandoned pastures (AP1, AP2, AP3, AP4), Itaboraí, RJ, Brazil. Acar: Acari; Arch: Archaeognatha; Auch: Auchenorryncha; Cole: Coleoptera; Dipl: Diplopoda; Ento: Entomobryomorpha; Form: Formicidae; Pseu: Pseudoscorpionida; Psoc: Psocoptera; Ster: Sternorryncha; Symp: Symphyla; Thys: Thysanura

The areas of abandoned pasture, where Acari, Araneae, Formicidae, Diplopoda and Auchenorrhyncha were the most favored taxonomic groups, presented higher values of uniformity and diversity compared to the average for the forest fragments.

Compared to the forest fragments, the highest values of total abundance, richness, uniformity and diversity were observed in intermediate stages of Atlantic forest succession.

Sternorryncha, Symphyla and Thysanura presented higher correlation with the forest fragment in initial successional stage.

Coleoptera, Psocoptera, Pseudoscorpionida, Entomobryomorpha and Archaeognatha correlated with the set of other Atlantic Forest fragments, which were present in intermediate and advanced successional stages.

\section{References}

Aquino, A.M. 2001. Manual para macrofauna do solo. Embrapa Agrobiologia, Seropédica, RJ. 21 p. (Documentos, 130).
Araújo, V.F.P., Bandeira, A.G., Vasconcellos, A. 2010. Abundance and stratification of soil macroarthropods in a Caatinga Forest in Northeast Brazil. Brazilian Journal of Biology 70 : 737-746.

Baretta, D., Santos, J.P.C., Segat, J.C., Geremia, E.V., Oliveira Filho, L.C.L., Alves, M.V. 2011 . Fauna edáfica e qualidade do solo. In: Klauberg Filho, O., Mafra, A.L., Gatiboni, L. C. Tópicos em Ciências do solo. Sociedade Brasileira de Ciência do Solo, Viçosa, MG, v. 7, p. 141-192.

Camara, R., Correia, M.E.F., Villela, D.M. 2012. Effects of eucalyptus plantations on soil arthropod communities in a Brazilian Atlantic Forest conservation. Bioscience Journal 28: 445455.

Copatti C.E., Daudt, C.R. 2009. Diversidade de artrópodes na serapilheira em fragmentos de mata nativa e Pinus elliottii (Engelm. var elliottii). Ciência e Natura 31: 95-113.

Correia, M.E.F., Andrade, A.G. 2008. Formação de serapilheira e ciclagem de nutrientes. In: Santos, G.A., Camargo, F.A.O. (ed.) Fundamentos da matéria orgânica do solo: ecossistemas tropicais e subtropicais. Gênesis, Porto Alegre, RS. p. 137170. 
Cunha, H.F., Orlando, T.Y.S. 2011. Functional composition of termite species in areas of abandoned pasture and in secondary succession of the Parque Estadual Altamiro de Moura Pacheco, Goiás, Brazil. Bioscience Journal 27: 986-992.

Decaëns, T., Jiménez, J.J., Barros, E., Chauvel, A., Blanchart, E., Fragoso, C., Lavelle, P. 2004. Soil macrofaunal communities in permanent pastures derived from tropical forest or savana. Agriculture, Ecosystems and Environment 103: p.301-312.

Fernandes, M.M., Magalhães, L.M.S., Pereira, M.G., Correia, M.E.F., Brito, R.J., Moura, M.R. 2011. Influência de diferentes coberturas florestais na fauna do solo na Flona Mário Xavier, no município de Seropédica, RJ. Floresta 41: 533-540.

Fidalgo, E.C.C., Prado, R.B., Resende, A.S., Curcio, G.R., Chaer, G.M., Bonnet, A., Correia, M.E.F. 2014. Estratégia metodológica para O monitoramento. In: Prado, R.B., Fidalgo, E.C.C., Bonnet, A. (ed.) Monitoramento da revegetação do COMPERJ: etapa inicial. Embrapa, Brasília, DF. p. 37-48.

Gomes, J.G., Pereira, M.G., Piña-Rodrigues, F.C.M., Pereira, G.H.A., Gondim, F.R., Silva, E.M.R. 2010. Aporte de serapilheira e de nutrientes em fragmentos florestais da Mata Atlântica, RJ. Revista Brasileira de Ciências Agrárias 5: 383-391.

Gomes, J.S., Silva, A.C.B.L., Rodal, M.J.N., Silva, H.C.H. 2009. Estrutura do sub-bosque lenhoso em ambientes de borda e interior de dois fragmentos de Floresta Atlântica em Igarassu, Pernambuco, Brasil. Rodriguésia 60: 295-310.

Gomes, J.B.V., Curcio, G.R., Dedecek, R.A., Ramos, M.R. 2014. Atributos químicos e mineralógicos. In: Prado, R.B., Fidalgo, E.C.C. Bonnet, A. (ed.) Monitoramento da revegetação do COMPERJ: etapa inicial. Embrapa, Brasília, DF. p. 103-118.

Gonçalves, A.O. Caracterização climática. In: Prado, R.B., Fidalgo, E.C.C., Bonnet, A. (ed.) Monitoramento da revegetação do COMPERJ: etapa inicial. Embrapa, Brasília, DF. p. 65-81.

Hammer, Ø., Harper, D.A.T., Ryan, P.D. 2001. PAST: Paleontological statistics software package for education and data analysis. Palaeontologia Electronica 4: 1-9. http://paleo-electronica. org/2001_1/past/issuel_01.htm. <Acesso em 14 abr. 2015>

Holanda, A.C., Feliciano, A.L.P., Marangon, L.C., Santos, M.S., Melo, C.L.S.M.S., Pessoa, M.M.L. 2010. Estrutura de espécies arbóreas sob efeito de borda em um fragmento de Floresta Estacional Semidecidual em Pernambuco. Revista Árvore
34: 103-114.

Hooper, D.U., Chapin, F.S., Ewel, J.J., Hector, A., Inchausti, P., Lavorel, S., Lawton, J.H., Lodge, D.M., Loreau, M., Naeem, S., Schmid, B., Setälä, H., Symstad, A.J., Vandermeerand, J., Wardle, D.A. 2005. Effects of biodiversity on ecosystem functioning: a consensus of current knowledge. Ecological Monographs 75: 3-35.

Köppen, W. 1948. Climatologia: con un estudio de los climas de la Tierra. Fondo de Cultura Economica, Mexico. 478 p.

Machado, D.L., Pereira, M.G., Correia, M.E.F., Diniz, A.R., Menezes, C.E.G. 2015. Fauna edáfica na dinâmica sucessional da Mata Atlântica em floresta estacional semidecidual na bacia do Rio Paraíba do Sul - RJ. Ciência Florestal 25: 91-106.

Martins, L., Almeida, F.S., Mayhé-Nunes, A.J., Vargas, A.B. 2011. Efeito da complexidade estrutural do ambiente sobre as comunidades de formigas (Hymenoptera: Formicidae) no município de Resende, RJ, Brasil. Revista Brasileira de Biociências 9: 74-179.

Mathieu, J., Rossi, J.-P., Mora, P., Lavelle, P., Martins, P.F.S., Rouland, C., Grimaldi, M. 2009. Recovery of soil macrofauna communities after forest clearance in Eastern Amazonia, Brazil. Conservation Biology 19: 598-1605.

Menezes, C.E.G., Correia, M.E.F., Pereira, M.G., Batista, I., Rodrigues, K.M., Couto, W.H., Anjos, L.H.C., Oliveira, I.P. 2009. Macrofauna edáfica em estádios sucessionais de floresta estacional semidecidual e pastagem mista em Pinheiral (RJ). Revista Brasilleira de Ciência do Solo 33: 1647-1656.

MoçO, M.K.S., Gama-Rodrigues, E.F., GamaRodrigues, A.C., Correia, M.E.F. 2005. Caracterização da fauna edáfica em diferentes coberturas vegetais na região norte fluminense. Revista Brasilleira de Ciência do Solo 29: 555-564.

Nakamura, A., Catterall, C.P., House, A.P.N., Kitching, R.L.L., Burwell, C.J. 2007. The use of ants and other soil and litter arthropods as bioindicators of the impacts of rainforest clearing and subsequent land use. Journal of Insect Conservation 11: 177-186.

Pereira, G.H.A., Pereira, M.G., Anjos, L.H.C., Amorim, T.A., Menezes, G.E.G. 2013. Decomposição da serrapilheira, diversidade e funcionalidade de invertebrados do solo em um fragmento de floresta atlântica. Bioscience Journal 29: 1317-1327. 
Sabu, T.K., Shiju, R.T., Vinod, K.V., Nithya, S. 2011. A comparison of the pitfall trap, Winkler extractor and Berlese funnel for sampling ground-dwelling arthropods in tropical montane cloud forests. Journal of Insect Science 11:1-19.

Sayad, E., Hosseini, S.M., Hosseini, V., SaleheShooshtari, M.-H. 2012. Soil macrofauna in relation to soil and leaf litter properties in tree plantations. Journal of Forest Science 58: 170-180.

Sayer, E.J. 2006. Using experimental manipulation to assess the roles of leaf litter in the functioning of forest ecosystems. Biological Reviews 81: 1-31.

Siqueira, L.P.; Matos, M.B.; Matos, D.M.S.; Portela, R.C.Q.; Braz, M.I.G.; Silva-Lima, L. 2004. Using the variances of microclimate variables to determine edge effects in small Atlantic Rain Forest fragments, south-eastern Brazil. Ecotropica 10: p. 59-64.

Sylvain, Z.A., Wall, D.H. 2011 . Linking soil biodiversity and vegetation: implications for a changing planet. American Journal of Botany 98: 517-527.

Uhlmann, A., Bonnet, A., Curcio, G.R., Silva, A.P., Gonçalves, F.L.A., Resende, A.S. 2014. A cobertura vegetal das florestas e pastagens. In: Prado, R.B., Fidalgo, E.C.C., Bonnet, A. (ed.) Monitoramento da revegetação do COMPERJ: etapa inicial. Embrapa, Brasilia, DF. p. 223-244.

Veloso, H.P., Rangel Filho, A.L.R., Lima, J.C.A. 1991. Classificação da vegetação brasileira adaptada a um sistema universal. IBGE, Rio de Janeiro, RJ. 124 p. 